\title{
Inhibitory effect of sodium metabisulphite and chlorine on growth of Aspergillus spp. and Penicillium spp. strains isolated from marine shrimp
}

\author{
Efeito inibitório do metabissulfito de sódio e do cloro sobre o crescimento de cepas de \\ Aspergillus spp. e Penicilium spp. isoladas de camarão marinho
}

\author{
Ygor Flávio de Moraes Santos ${ }^{\mathrm{I}, \mathrm{III} *}$ Átyla Peeter Batista Veloso ${ }^{\mathrm{I}}$ Rodrigo Maciel Calvet $^{\mathrm{I}, \mathrm{III}}$ \\ Maria Marlúcia Gomes Pereira ${ }^{\mathrm{I}}$ Carina Maricel PereyraII Ana Maria Dalcero ${ }^{\mathrm{II}}$ \\ Adriana Mabel Torres ${ }^{\mathrm{II}}$ Maria Christina Sanches Muratori ${ }^{\mathrm{I}}$
}

\section{ABSTRACT}

The sodium metabisulphite (SMB) is used in shrimp farming to prevent melanosis and the $5.0 \mathrm{ppm}$ chlorine $(\mathrm{CL})$ concentration used in the shrimp processing is efficient as a bactericide, but there is no evidence of the effectiveness of these chemical compounds as fungicides. Therefore, the aim of this study was to evaluate the in vitro effect of sodium metabisulphite $(S M B)$ and chlorine (CL) on the growth of Aspergillus and Penicillium species isolated from marine shrimp in different stages of processing. The samples were collected from a frozen shrimp processing industry, located in Piaui State, Brazil. The total fungi and occurrence of Aspergillus and Penicillium species were evaluated. For in vitro sensibility test using the diffusion disk in agar method, five concentrations of SMB $(0 \%, 1 \%, 3 \%, 5 \%$ and $10 \%)$ and six of $C L\left(0,1,2,3,4\right.$ and $\left.5 \mu \mathrm{g} \mathrm{mL}^{-1}\right)$ were used. The fungal counts in the different processing stages ranged from 1.74

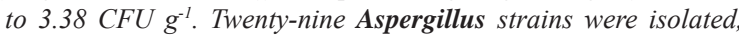
prevailing A. versicolor (59.3\%) and twenty-two of Penicillium, prevailing $\boldsymbol{P}$. citrinum (74\%). One strain of A. flavus was $A F B_{l}$ producer. All the isolated strains of $\boldsymbol{P}$. citrinum produced citrinin. All tested species were in vitro sensitive to $3 \%$ of SMB, except the A. flavus. The $10 \%$ concentration of SMB inhibited the in vitro growth of all strains. The CL concentrations tested did not inhibit the studied species growth and SMB concentrations above $3.0 \%$ inhibited in vitro the growth of the tested strains.

Key words: Aspergillus flavus, Litopenaeus vannamei, Penicillium citrinum, shrimp culture, conservation.

\section{RESUMO}

O metabissulfito de sódio (SMB) é usado na carcinicultura para evitar a melanose e a concentração de 5,0ppm de cloro (CL), utilizada no beneficiamento do camarão, é eficiente como bactericida, porém não há comprovação da eficácia destes compostos químicos como fungicida. Desse modo, o objetivo deste estudo foi avaliar o efeito in vitro do metabissulfito de sódio (SMB) e cloro (CL) sobre o crescimento de espécies de Aspergillus e Penicillium isolados de camarão marinho em diferentes estágios de processamento. As amostras foram coletadas de uma indústria de processamento de camarão congelado, localizada no Estado do Piauí, Brasil. Fungos totais e ocorrência das espécies de Aspergillus e Penicillium foram avaliados. Para o teste in vitro de sensibilidade pelo método disco-difusão em ágar, foram utilizadas cinco concentrações de SMB $(0 \%, 1 \%, 3 \%, 5 \%$ e $10 \%)$ e seis de $C L\left(0,1,2,3,4\right.$ e $\left.5 \mu \mathrm{g} m L^{-1}\right)$. As contagens fúngicas nos diferentes estágios de processamento variaram de 1,74 a 3,38UFC $g^{-1}$. Foram isoladas 29 cepas de Aspergillus, prevalecendo o A. versicolor (59,3\%) e 22 de Penicillium, prevalecendo o P. citrinum (74\%). Uma cepa de A. flavus era produtora de $A F B_{I}$. Todas as cepas de $\boldsymbol{P}$. citrinum isoladas produziram citrinina. Todas as espécies testadas foram sensiveis in vitro a 3\% do SMB, com exceção do A. flavus. A concentração de $10 \%$ do SMB inibiu in vitro o crescimento de todas as cepas. As concentrações de CL testadas não inibiram o crescimento das espécies isoladas e concentrações de SMB acima de 3,0\% inibiram in vitro o crescimento das linhagens testadas.

Palavras-chave: Aspergillus flavus, Litopenaeus vannamei, Penicillium citrinum, carcinicultura, conservação.

\section{INTRODUCTION}

The shrimp culture is an important activity practiced in the coast of the Piauí State, Brazil, which generates foreign exchange and is an important source of employment for the local people. In 2009, Brazilian production was 65.000 tons of shrimp, of which 843 tons of shrimp were from the State of Piauí (ABCCam, 2011).

\footnotetext{
'Departamento de Morfofisiología Veterinária, Centro de Ciências Agrárias (CCA), Universidade Federal do Piauí (UFPI), Teresina, PI, Brasil. IIDepartamento de Microbiología e Inmunología, Universidad Nacional de Río Cuarto, Río Cuarto, Córdoba, Argentina.

IIIPrograma de Pós-graduação em Ciência Animal, CCA, UFPI, 64049-550, Teresina, PI, Brasil. E-mail: ygorflavio@gmail.com.*Autor para correspondência. 
Fungi are widely distributed in nature and because of this can be used as parameters for determining microbiological hygienic conditions of the culture environment. Some fungi are capable of producing secondary toxic metabolites and sometimes carcinogenic to animals and humans. Its biosynthesis is related to environmental conditions such as temperature, humidity and rainfall during the growing season, harvesting, post harvest and storage of agricultural products (PITT \& HOCKING, 1999; SAMSOM et al., 2001). Aspergillus spp., Penicillium spp. and Fusarium spp. are the most commonly filamentous moulds found in stored cereal grains and feeds. Thus, the hot and humid climate is conducive to growth of fungi in stored foods and therefore conducive to mycotoxin production (BINTVIHOK et al., 2003).

Due to the importance of the shrimp to the brazilian economy and the increasingly sharp demands of importing countries, and the quality of final product, it is necessary to develop and enhancement techniques for postharvest processing of shrimp. Sodium metabisulphite - $\mathrm{SMB}\left(\mathrm{Na}_{2} \mathrm{~S}_{2} \mathrm{O}_{5}\right.$. $\mathrm{H}_{2} \mathrm{O}$ ) is used in shrimp culture, in order to avoid "black spot" or melanosis on post-harvest shrimp. This is a preservative for greater stability and which has the highest amount of sulfur dioxide $\left(\mathrm{SO}_{2}\right)$, when diluted with water (SILVA, 1988). For this reason, sulphites are multifunctional agents and are capable of controlling microbial growth in foods (LAURILA et al., 1998). The fish processing industries use $5.0 \mu \mathrm{g} \mathrm{mL}^{-1}$ of chlorine (CL) concentration during all processing steps in order to avoid bacterial growth (JAY, 2005).

There are several studies about SMB action on bacteria such as Salmonella spp., Clostridium spp., Pseudomonas spp., Vibrio spp., Staphylococcus spp., Bacillus spp., (VIEIRA, 2004). However have no evidence of the effectiveness of these chemical compounds as a fungicide on post-harvest shrimp.

The objective was to evaluate the effect in vitro of sodium metabisulphite and chlorine on growth and survival of Aspergillus and Penicillium species in cultured marine shrimp.

\section{MATERIALS AND METHODS}

\section{Source of samples}

The samples were collected from a shrimp processing industry located in the coast area of Piauí State, Brazil (region enclosed between $2^{\circ} 55^{\prime}$ $51,39^{\prime \prime} \mathrm{S}-2^{\circ} 58^{\prime} 04,31^{\prime \prime} \mathrm{S}$ a $41^{\circ} 20^{\prime} 09,35^{\prime \prime} \mathrm{W}-41^{\circ} 26^{\prime}$ $\left.33,52^{\prime \prime} \mathrm{W}\right)$. A total of 36 samples with $100 \mathrm{~g}$ of shrimp was obtained from six different points classified as "A" (time of harvest before the addition of SMB), point "B" (after the addition of SMB), point "C" (reception industry after washing the shrimp amounts with chlorinated water to $5.0 \mu \mathrm{g} \mathrm{mL}^{-1}$ ); point " $\mathrm{D}$ "(for the handling and removal of the carapace in the wake of processing); point "E" (after exoskeleton removal); and point " $\mathrm{F}$ " (at the exit of the freezing tunnel at $-35^{\circ} \mathrm{C}$ ). After collection, the samples were placed in plastic sterile sealed bags Nasco Whirl-Pak ${ }^{\circledR}$, identified and transported in containers containing ice packs to the Laboratory of Microbiological Control of Food, of Centre of Agrarian Sciences of Federal University of Piauí, Brazil.

Mycological determination and identification of Aspergillus and Penicillium species

Total fungal counts from samples were performed into Dichloran Rose Bengal Chloranphenicol Agar (DRBC), recommended by PITT \& HOCKING (1999). Quantitative enumeration was done using the surface-spread method. Twentyfive grams of each sample were homogenized in $225 \mathrm{~mL} 0.1 \%$ peptone water solution for $30 \mathrm{~min}$ in an orbital shaker. Serial dilutions $\left(10^{-2}\right.$ to $\left.10^{-3}\right)$ were made and $0.1 \mathrm{~mL}$ aliquots were inoculated in duplicates onto the culture media. Plates were incubated at $25^{\circ} \mathrm{C}$ for 7-10 days in darkness. Only plates containing 10-100 colony-forming units (CFU) were used for counting. The results were expressed as CFU per gram of sample $\left(\mathrm{CFU} \mathrm{g}{ }^{-1}\right)$. Representative colonies of Aspergillus and Penicillium spp. were transferred for sub-culturing to tubes containing Malt Extract Agar (MEA). Identification of Aspergillus and Penicillium species was performed according to taxonomic keys (KLICH, 2002; SAMSON \& FRISVAD, 2004; PITT, 2004).

\section{Aflatoxin $\mathrm{B}_{1}$ production by Aspergillus flavus}

All Aspergillus flavus strains isolated from shrimp were assayed for aflatoxin $\mathrm{B}_{1}\left(\mathrm{AFB}_{1}\right)$ production. The strains were grown on MEA plates at $28^{\circ} \mathrm{C}$ for 7 days. The mycelium was transferred to an Eppendorf tube and $1000 \mu \mathrm{L}$ chloroform was added. The mixture was shaken for $20 \mathrm{~min}$ at room temperature, the mycelium was removed and the chloroform extract evaporated to dryness under $\mathrm{N}_{2}$ flow. The residue was redissolved in $200 \mu \mathrm{L}$ de chloroform. The extracts were analyzed by Thin Layer Chromatography (TLC) on silica gel 60 F254 TLC aluminum sheets $(20 \times 20 \mathrm{~cm}, 250 \mathrm{~mm}$ thick, Merk, Germany). The eluent used was chloroform: acetone $\left(90: 10, \mathrm{~V} \mathrm{v}^{-1}\right)$. The chromatographic run was carried out at room temperature in a vat of glass. 
The observation was carried out under the plates with ultraviolet light of wavelength $360 \mathrm{~nm}$ and the concentration of AFs method was determined by visual comparison of the retention factors and the fluorescence intensity. Detection limit of the used method was $5 \mu \mathrm{g} \mathrm{kg}^{-1}$ (GEISEN, 1996).

\section{Citrinin production by Penicillium citrinum}

Penicillium citrinum strains isolated were assayed for citrinin production, respectively. The detection of toxins was performed following the methodology proposed by CRUZ et al. (1992). They were preserved on MEA at $4^{\circ} \mathrm{C}$ until use. The strains were grown in media Coconut Agar (CAM) at $28^{\circ} \mathrm{C}$ for 7 days. Three agar plugs were removed from the central area of the colony, weighed and introduced into a small vial. A volume of $1 \mathrm{~mL}$ of chloroform was added to each vial, the sample-solvent mixture was centrifuged for $10 \mathrm{~min}$ at $1400 \mathrm{rpm}$. The plugs were removed and the chloroform extract was evaporated to dryness under $\mathrm{N}_{2}$ flow. The residue was re-dissolved in $100 \mu \mathrm{L}$ chloroform. Extracts were analyzed by TLC on silica gel 60 F254 TLC aluminum sheets (20x20cm, 250 $\mu \mathrm{m}$ thickness, Merck, Germany). The developing solvent was toluene: acetate of ethyl: chloroform: formic acid (70:50:50:10). The plates were previously impregnated with $10 \%$ oxalic acid in ethanol.

Sensitivity test in vitro of Aspergillus spp. and Penicillium spp.

Four strains of Aspergillus (A. flavus, A. versicolor, $A$. terreus and $A$. niger aggregate) and five of Penicillium (P. citrinum, P. implicatum, $\boldsymbol{P}$. citreonigrum, $P$. purpurogenum and $P$. decumbens) isolated from shrimp samples collected at different points ("A", "B", "C", "D", "E" and "F") were in vitro tested for sensibility to SMB and CL by the diffusion disk in agar method (NCCLS / CLSI, 2004) using four concentrations of $\operatorname{SMB}(0,1,3,5$ and $10 \%)$ and five concentrations of $\mathrm{CL}(0,1,2,3,4$, $\left.5 \mu \mathrm{g} \mathrm{ml}^{-1}\right)$. All tests were performed in duplicate with four replicates each. The filter paper discs $(20 \mathrm{~mm}$ of diameter) were sterilized and subsequently immersed in concentrations of SMB and CL.

To prepare the inoculums, the recommendations of ESPINEL-INGROFF et al. (1997) and the NCCLS / CLSI (2009) were followed, as follows: conidial suspensions were prepared using one to five Aspergillus and Penicillium colonies $(<5 \mathrm{~mm}$ of diameter) grown in MEA for seven days at $25^{\circ} \mathrm{C}$. The colonies were covered with $1.0 \mathrm{~mL}$ of sterile saline solution at $0.85 \%$ and were homogenized with a pipette preparing a suspension. One drop of Tween 20 was added to facilitate the inoculum preparation. The resulting mixture of conidia and hypha fragments was removed and transferred to a sterile test tube. After the particles sedimentation (3 to 5 minutes), the supernatant was transferred to another sterile tube and homogenized in a mixer for 15 seconds. Each fungal suspension was adjusted to contain 1x106 to $5,0 \times 106 \mathrm{CFU} \mathrm{mL} \mathrm{m}^{-1}$, first, by comparison the turbidity with the $0.5 \mathrm{McF}$ arland scale tube.

The densities of the conidial suspensions were read and adjusted to an optical density that ranged from 0.09 to 0.11 ( $80-82 \%$ of transmittance) in a spectrophotometer at 530nm, hemocytometer counting and counting of colony forming units (CFUs) in MEA. Subsequently, the suspensions were poured into Petri dishes with MEA where paper discs were added on three equidistant points. The plates were incubated at $25^{\circ} \mathrm{C}$ for seven days. After the incubation period, the fungal growth and sensibility to the tested compounds was observed.

\section{Statistical analysis}

Data analyses were performed by variance analysis. Total fungal counts data were transformed using a logarithmical function $\log _{10}(x+1)$ before applying the variance analysis.

\section{RESULTS AND DISCUSSION}

Table 1 shows fungal total medium counts on the DRBC from different stages of shrimp processing ranged from 1.74 to $3.38 \log _{10} \mathrm{CFU} \mathrm{g}{ }^{-1}$. There were no differences between the different stages of processing $(\mathrm{P}<0.05)$. However, some shrimp samples of point "C" had fungal counts above the recommended limit $\left(3.0 \log _{10} \mathrm{CFU} \mathrm{\textrm {g } ^ { - 1 }}\right)$. This results are similar with others authors who worked with shrimp feed, water and nurseries substrate of the same industry, indicating that fungal were found in the environment culture in constant amounts after post harvest and processing industrial (CALVET et al., 2007). Fungal counts of the stage that shrimp amounts were washed with chlorinated water, was the only stage with counts above the recommended limit $\left(3.0 \log _{10}\right.$ CFU g $\left.{ }^{-1}\right)$. REIS et al. (2004) analyzed shrimp samples trade collected in Sao Paulo, whose values ranged between 3.04 at $7.36 \log _{10} \mathrm{CFU} \mathrm{g}^{-1}$ if kept under refrigeration. These authors say that the incorrect management after the expedition may advantage the fungal growth pre-existing during marketing.

Table 2 shows relative density (\%) of Aspergillus spp. and Penicillium spp. isolated from shrimp at different productions stages. Twenty nine 
Table 1 - Fungal counts $\left(\mathrm{CFU} \mathrm{\textrm {g } ^ { - 1 }}\right)$ from shrimp at different productions stages.

\begin{tabular}{lc}
\hline Different productions stages & Fungal counts $\left(\mathrm{CFU} \mathrm{g}^{-1}\right.$ in $\left.\log _{10}\right) \mathrm{Media}^{\mathrm{a}}$ \\
\hline Before the addition of SMB (A) & $2.81^{\mathrm{a}}$ \\
After the addition of SMB (B) & $2.50^{\mathrm{a}}$ \\
Washing the shrimp excessive amounts of chlorine (C) & $3.11^{\mathrm{a}}$ \\
Handling and removal of the carapace (D) & $2.56^{\mathrm{a}}$ \\
After removal of the exoskeleton (E) & $2.45^{\mathrm{a}}$ \\
Exit of the tunnel of freezing at $-35^{\circ} \mathrm{C}(\mathrm{F})$ & $2.64^{\mathrm{a}}$ \\
\hline
\end{tabular}

$\mathrm{CFU}=$ colony-forming units; $\mathrm{SMB}=$ Sodium metabisulphite; Maximum recommended level: $3.0 \mathrm{CFU} \mathrm{g} \mathrm{g}^{-1}$ in $\log _{10}$.

Aspergillus spp. strains were isolated. Aspergillus versicolor was the predominant species (59.3\%) followed by A. flavus (33.3\%). Aspergillus terreus and $\boldsymbol{A}$. niger aggregate were isolated at low frequency (3.7\%). Twenty two Penicillium spp. strains were isolated from shrimp. Penicillium citrinum was the predominant species $(74.0 \%)$ followed by $\boldsymbol{P}$. implicatum (14.0\%). Penicillium citreonigrum, $\boldsymbol{P}$. purpurogenum and $\boldsymbol{P}$. decumbens were isolated at a relative density from $4.0 \%$.

Several studies have shown that shrimp have species from Aspergillus and Penicillium genera as predominant mycoflora (LEAÑO et al., 2005; CALVET, 2008). The dominance of filamentous fungi indicates that these fungi can proliferate very well in this substrate. Among the filamentous fungi, the dominant genera observed (Penicillium and Aspergillus spp.) are toxins producers and pathogenic to shrimps (e.g. Aspergillus and Fusarium spp.) (LEAÑO, 2001).

From the nine A. flavus isolated, one strain (11.1\%) of stage "F" was $\mathrm{AFB}_{1}$ producer. YOUSEFI et al. (2009) isolated A. flavus strains producing of $\mathrm{AFB}_{1}$ as mycoflora from cultured green tiger shrimps
(Penaeus semisulcatus) and water of their ponds. The presence of these fungal species isolated from shrimp at different stages of processing may be due to environmental contamination or feed contaminated with these species in the culture environment (CALVET, 2008; YOUSEFI et al., 2009).

In this study, $\boldsymbol{P}$. citrinum was the most prevalent species isolated from shrimp. All strains of $\boldsymbol{P}$ c citrinum were positive for citrinin production. Although the citrinin is not carcinogenic it has nephrotoxic effects (PITT, 2004). These results are similar to those obtained by CALVET (2008), who reported the presence of toxigenic $\boldsymbol{P}$. citrinum in storage sheds containing shrimp feed.

The inhibitory effect of SMB on Aspergillus spp. and Penicillium spp. strains growth by diffusion agar method shown in table 3. Aspergillus terreus, $\boldsymbol{P}$. citrinum, $\boldsymbol{P}$. implicatum and $\boldsymbol{P}$. decumbens were sensitive to $1 \%$ SMB concentrations. Aspergillus flavus was the only species resistant to 3\% SMB concentrations. All studied strains were sensitive to 5 and $10 \%$ SMB concentrations. Chlorine concentrations studied were not effective in inhibiting the growth of the tested strains (data not shown).

Table 2 - Relative density (\%) of Aspergillus spp. and Penicillium spp. isolated from shrimp at different productions stages.

\begin{tabular}{lccc}
\hline Species & Relative density (\%) & Productions Stages & Number of Isolates \\
\hline A. versicolor & 59.3 & C, D, F & $16.0^{\mathrm{a}}$ \\
A. flavus & 33.3 & A, B, E, F & $9.0^{\mathrm{b}}$ \\
A. terreus & 3.7 & $\mathrm{~F}$ & $1.0^{\mathrm{c}}$ \\
A. niger aggregate & 3.7 & $\mathrm{C}$ & $1.0^{\mathrm{c}}$ \\
P. citrinum & 74.0 & $\mathrm{~A}, \mathrm{~B}, \mathrm{C}, \mathrm{D}, \mathrm{F}$ & $16.0^{\mathrm{a}}$ \\
$\boldsymbol{P}$. implicatum & 14.0 & $\mathrm{~B}, \mathrm{C}$ & $3.0^{\mathrm{b}}$ \\
$\boldsymbol{P}$. citreonigrum & 4.0 & $\mathrm{~A}$ & $1.0^{\mathrm{c}}$ \\
$\boldsymbol{P}$. purpurogenum & 4.0 & $\mathrm{E}$ & $1.0^{\mathrm{c}}$ \\
$\boldsymbol{P}$. decumbens & 4.0 & $\mathrm{E}$ & $1.0^{\mathrm{c}}$ \\
\hline
\end{tabular}

$\mathrm{a}, \mathrm{b}, \mathrm{c}=$ Letters are similar results in the same column. $\chi^{2}=30,96(\mathrm{P}<0,05) \mathrm{A}=$ Before the addition of Sodium metabisulphite; $\mathrm{B}=\mathrm{After}$ the addition of Sodium metabisulphite; $\mathrm{C}=$ Washing the shrimp excessive amounts of chlorine; $\mathrm{D}=\mathrm{Handling}$ and removal of the carapace; $\mathrm{E}=$ After removal of the exoskeleton; $\mathrm{F}=$ Exit of the tunnel of freezing at $-35^{\circ} \mathrm{C}$. 
Table 3 - Inhibitory effect of growth in vitro of sodium metabisulphite on species Aspergillus and Penicillium.

\begin{tabular}{|c|c|c|c|c|c|}
\hline \multirow{2}{*}{ Species } & \multicolumn{5}{|c|}{---Sodium metabisulphite (\%)-- } \\
\hline & 0,0 & 1,0 & 3,0 & 5,0 & 10,0 \\
\hline A. niger agregados & $\mathrm{R}$ & $\mathrm{R}$ & $\mathrm{S}$ & $\mathrm{S}$ & $\mathrm{S}$ \\
\hline A. terreus & $\mathrm{R}$ & $\mathrm{S}$ & $\mathrm{S}$ & $\mathrm{S}$ & S \\
\hline A. versicolor & $\mathrm{R}$ & $\mathrm{R}$ & $\mathrm{S}$ & $\mathrm{S}$ & S \\
\hline A. flavus & $\mathrm{R}$ & $\mathrm{R}$ & $\mathrm{R}$ & $\mathrm{S}$ & S \\
\hline P. citrinum & $\mathrm{R}$ & $\mathrm{S}$ & $\mathrm{S}$ & S & S \\
\hline P. implicatum & $\mathrm{R}$ & $\mathrm{S}$ & S & S & S \\
\hline P. citreonigrum & $\mathrm{R}$ & $\mathrm{R}$ & $\mathrm{S}$ & S & S \\
\hline P. purpurogenum & $\mathrm{R}$ & $\mathrm{R}$ & $\mathrm{S}$ & S & S \\
\hline P. decumbens & $\mathrm{R}$ & $\mathrm{S}$ & $\mathrm{S}$ & $\mathrm{S}$ & $\mathrm{S}$ \\
\hline
\end{tabular}

$\mathrm{R}=$ resistant $\quad \mathrm{S}=$ sensitive

The industry investigated using 6\% SMB solutions for shrimp immersion for 15 to $20 \mathrm{~min}$, after post collect and so prevents the occurrence of melanose and bacterial growth (SILVA, 1988; BARBIERI \& OSTRENSKY, 2002). This concentration of SMB did not inhibit fungal growth during the processing stages, it was demonstrated by fungal counts in different stages. However, the use of $5 \%$ SMB totally inhibited strains tested in vitro. The use of SMB is known against phytopathogenic fungi and bacteria, but little is known about these storage fungi in shrimp (GÓES et al., 2006; PATSOUKIS \& GEORGIOU, 2007).

The chlorine concentration used $(5 \mu \mathrm{g}$ $\mathrm{mL}^{-1}$ ) is efficient as a bactericide but not fungistatic, due to the presence of fungi during all stages of processing and inefficient to inhibit the strains tested in vitro (JAY, 2005). In general, filamentous fungi are more resistant than yeasts and bacteria. Studies with different chemicals were not effective to inhibit the growth of Aspergillus and Penicillium species and inadequate chemicals doses can promote fungal growth (XAVIER et al., 2007; CHAPMAN, 1998).

This is the first preliminary work that shows the SMB and CL effect on growth of Aspergillus and Penicillium species isolated from marine shrimp in different stages of processing. Future studies should be conducted to see how SMB and CL can affect the parameters of growth and toxin production.

\section{ACKNOWLEDGMENT}

This work was carried out with grants from Conselho Nacional de Desenvolvimento Científico e Tecnológico (CNPq),
Universidade Federal do Piauí (UFPI), Brazil, Universidade Federal Rural do Rio de Janeiro (UFRRJ), Brazil and Universidad Nacional de Río Cuarto, (UNRC), Argentina.

\section{REFERENCES}

ABCCam (ASSOCIAÇ̃̃O BRASILEIRA DE CRIADORES DE CAMARÃO). Estatísticas do setor pesqueiro e da carcinicultura brasileira. Available from: <http://www.abccam.com.br/abcc/ images/stories/estatisticas/Estatstica_DO_SETOR_PESQUEIRO. pdf $>$. Online. Accessed: Ago. 25, 2011

BARBIERE, J.R.C.; OSTRENSKY, N.A. Camarão marinho: engorda. Viçosa: Aprenda Fácil, 2002. 352p.

BINTVIHOK, A. et al. Aflatoxin contamination in shrimp feed and effects of aflatoxin addition on shrimp production. Journal of Food Protection, v.66, n.5, p.882-885, 2003.

CALVET, R.M. et al. Contagem de fungos filamentosos e leveduras em camarões cultivados. Revista Higiene Alimentar, v.21, n.150, p.253-251, 2007.

CALVET, R.M. Identificação e isolamento de fungos toxígenos em carcinicultura marinha. 2008. 82f. Dissertação (Mestrado em Ciência Animal) - Programa de Pós-graduação em Ciência Animal, Faculdade de Veterinária. Universidade Federal do Piauí

CHAPMAN, J.S. Characterizing bacterial resistance to preservatives and disinfectants. International Biodeterioration and Biodegradation, v.41, p.241-245, 1998.

CRUZ, L.C.H. et al. Aplicação do Ágar-Coco como meio diferencial para o isolamento de fungos citrinogênicos. Arquivos da Universidade Federal Rural do Rio de Janeiro, v.15, n.1, p.39-60, 1992.

ESPINEL-INGROFF, A. et al. Multicenter evaluation of proposed standardized procedure for antifungal susceptibility testing of filamentous fungi. Journal of Clinical Microbiology, v.35, n.1, p.139-143, 1997.

GEISEN, R. Multiplex polymerase chain reaction for the detection of potential aflatoxin and sterigmatocystin producing fungi. Journal of Applied Microbiology, v.19, p.388-392, 1996

Ciência Rural, v.43, n.9, set, 2013. 
GÓES, L.M.N. et al. Uso do metabissulfito de sódio no controle de microorganismos em camarões marinhos Litopenaeus vannamei (Boone, 1931). Acta Scientiarum. Biological Sciences, v.28, n.2, p.153-157, 2006.

JAY, J.M. Microbiologia de alimentos. 6.ed. Porto Alegre: Artmed, 2005. 712p.

KLICH, M.A. A laboratory guide to the common Aspergillus species and their teleomorphs. Australia: CSIRO - Division of Food Processing, 2002. 116p.

LAURILA, E. et al. The inhibition of enzymatic browning in minimally processed vegetables and fruits. AgBiotech News and Information, v.9, n.4, p.53-66, 1998.

LEAÑO, E.M. Fungal diseases. In: LIO-PO, G.D. et al Health management in aquaculture. Philippines: Aquaculture Department, Southeast Asian Fisheries Development Center, 2001. p. $45-53$.

LEAÑO, E.M. et al. Mycoflora of the 'green water' culture system of tiger shrimp Penaeus monodon Fabricius. Aquaculture Research, v.36, p.1581-1587, 2005.

NCCLS/ CLSI (NATIONAL COMMITTEE FOR CLINICAL LABORATORY STANDARDS/CLINICAL LABORATORY STANDARDS INSTITUTE). Reference method for antifungal disk diffusion susceptibility testing of yeasts; Approved guideline Second Edition. M44-A2, v.29, n.17. Wayne, 2009. 8p.

PATSOUKIS, N.; GEORGIOU, C.D. Effect of sulfite-hydrosulfite and nitrite on thiol redox state, oxidative stress and sclerotial differentiation of filamentous phytopathogenic fungi. Pesticide Biochemistry and Physiology, v.88, n.2, p.226-235, 2007.
PITT, J.I.; HOCKING, A.D. Fungi and food spoliage. 2.ed. New York: Springer Science Business Media, LLC, 2009. 419p.

PITT, J.I. Guía del laboratorio para la identificación de especies comunes de Penicillium. Australia: CSIRO - Division of Food Processing, 2004. 199p.

REIS, J. et al. Estudo higiênico-sanitário dos camarões dulcícolas Macrobrachium amazonicum e M. jelskii. Revista Higiene Alimentar, v. v.116/117, p.18, p.58-67. 2004.

SAMSON, R.A.; FRISVAD, J.C. Penicillium subgenus. Penicillium: new taxonomic schemes and mycotoxins and other extrolites. Netherlands: Centraalbureau voor Schimmelcultures, 2004. 243p.

SAMSON, R.A. et al. Introduction to food-and airborne fungi. Netherlends: Royal Netherlands Academy of Arts and Siences, 2001. 389p.

SILVA, R.R. Considerações sobre o uso e o mal uso de sais de sulfito em crustáceos. In: SEMINÁRIO SOBRE CONTROLE DE QUALIDADE NA INDÚSTRIA DE PESCADO, 1988, Santos, SP. Anais... Santos: Loyolap, 1988. p.244-259.

VIEIRA, R.H.S.F. Microbiologia, higiene e qualidade do pescado: teoria e prática. São Paulo: Varela, 2004. 380p.

XAVIER, M.O. et al. Atividade in vitro de três agentes químicos frente a diferentes espécies de Aspergillus. Arquivos do Instituto Biológico, v.74, p.49-53, 2007.

YOUSEFI, S. et al. Aflatoxin production by Aspergillus flavus isolates from green-tiger shrimps (Penaeus semisulcatus). Iranian Journal of Microbiology, v.1, n.4, p.18-22, 2009. 